\title{
Ecology of a highly abundant, introduced cyclopoid copepod in a temperate estuary
}

\author{
P. Bouley*, W. J. Kimmerer \\ Romberg Tiburon Center, San Francisco State University, 3152 Paradise Drive, Tiburon, California 94920, USA
}

\begin{abstract}
The cyclopoid copepod Limnoithona tetraspina (Oithonidae) was introduced into the San Francisco Estuary (SFE) in 1993 and within a year became the most abundant copepod in the low-salinity zone. L. tetraspina makes up $~ 95 \%$ (median) of the total adult copepods in the lowsalinity zone, and the biomass of adults is similar to that of 2 larger co-occurring calanoids, Pseudodiaptomus forbesi and Eurytemora affinis. The main goal of our research was to understand which food resources $L$. tetraspina uses in the low-salinity region of the SFE. Incubation experiments using natural water revealed feeding by $L$. tetraspina on mixotrophic and heterotrophic aloricate ciliates, but rarely on loricate tintinnids or diatoms. The co-occurring calanoids consumed similar prey, but also readily consumed diatoms. Capture and consumption of Strombidium spp. by L. tetraspina was confirmed visually, and experiments using cultured prey also showed that these copepods fed on motile phytoplankton but not on diatoms. Estimated grazing rates were low (median 2.3, range 0.6 to $8.3 \%$ body weight $\mathrm{d}^{-1}$ ); although these rates may be underestimates because of high concentrations of copepods in experimental containers, they are consistent with low specific egg production of females $\left(0.3 \pm 0.2 \%\right.$ body weight $\left.\mathrm{d}^{-1}\right)$. Low selectivity of one fish species for $L$. tetraspina suggests that this copepod may not be an important food resource for visually-selective fishes in the SFE. The low abundance of filter-feeding predators in this region of the estuary may be responsible for the high abundance of this cyclopoid copepod, despite its low potential population growth rate.
\end{abstract}

KEY WORDS: Estuary · Cyclopoid · Foodweb · Introduced species · Ciliates

\section{INTRODUCTION}

Small copepods in the family Oithonidae are among the most abundant and productive groups of zooplankton to occur in marine and estuarine waters across the globe (Turner 2004). Ecologically they may function as important prey sources for the larval stages of some key fishery species (Viñás \& Ramirez 1996), or conversely as energetic sinks in the metazoan foodweb (Atkinson \& Snÿder 1997). They directly influence the downward flux of calanoid fecal-pellet material in pelagic zones (González \& Smetacek 1994), contribute to the regeneration of nutrients supporting primary production (Hiromi 1995), and facilitate complex trophic interactions between the protozoan and metazoan foodwebs (Nakamura \& Turner 1997). Oithonids differ from the better-studied suspension-feeding calanoid copepods in being primarily raptorial predators that use hydromechanical signals to detect and capture motile prey (Svensen \& Kiørboe 2000).

Limnoithona spp. (Oithonidae, length $0.5 \mathrm{~mm}$ ) were first described from freshwater and brackish regions of the Yangtze River, China. The genus has been introduced to estuaries of the Eastern Pacific, most likely in the ballast water of trade ships originating from estuaries on the Asian continent (Orsi \& Ohtsuka 1999). Limnoithona spp. have been recorded in the northernmost low-salinity areas of the San Francisco Estuary (SFE) since 1979 (Orsi \& Ohtsuka 1999): L. sinensis was first detected in 1979, and L. tetraspina in 1993. Within a year of its introduction, L. tetraspina became the most abundant copepod to inhabit the low-salinity regions of the SFE and this pattern persists to date. 
The SFE is the second-largest estuary in the USA and may be the most heavily invaded estuary in the world (Cohen \& Carlton 1998), particularly by copepods in the low-salinity region, where the copepod fauna now resembles that of East Asia (Orsi \& Ohtsuka 1999). The trophic ecology of copepods in this estuary is not well studied; only 2 studies to date have addressed the energy sources used by copepods (Orsi 1995, Rollwagen Bollens \& Penry 2003). The main purpose of this study was to investigate the feeding ecology of Limnoithona tetraspina by studying its grazing behavior on naturally-occurring prey assemblages in Suisun Bay, a shallow embayment of the SFE with notably suppressed phytoplankton production (Alpine \& Cloern 1992, Kimmerer 2004). We also present egg production rates in relation to chlorophyll a (chl a) for L. tetraspina, as well as population biomass trends in relation to temperature, salinity, and the abundance and biomass of 2 co-occurring calanoids, Eurytemora affinis and Pseudodiamptomus forbesi. Additionally, we present evidence that $L$. tetraspina is rarely utilized by juvenile fishes in the SFE and likely represents an energetic dead-end in the metazoan foodweb.

\section{MATERIALS AND METHODS}

Suisun Bay is a brackish, river-dominated, shallow embayment (mean depth $=3$ meters), that makes up $\sim 5 \%$ of the total volume of the San Francisco Estuary (volume $=0.3 \times 10^{9} \mathrm{~m}^{-3}$, Kimmerer 2004) (Fig. 1). This embayment is a nutrient-rich, turbid, and net heterotrophic system with low phytoplankton production (Alpine \& Cloern 1992), that receives seasonallyvariable flows from the Sacramento-San Joaquin River Delta and is also strongly influenced by tides.

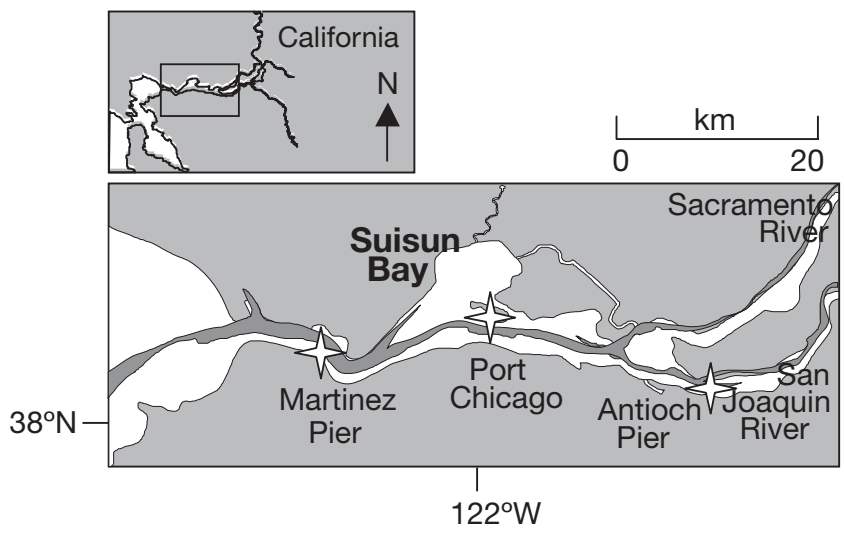

Fig. 1. Study sites for natural-water grazing experiments in northern San Francisco Estuary (SFE). Copepods and water samples were collected from piers along Suisun Bay, except for the May experiment when samples were collected offshore (from Port Chicago) using a boat
We obtained chl $a$, water temperature, and copepod abundance data from the California Interagency Ecological Program (IEP; www.iep.water.ca.gov) zooplankton monitoring survey for 3 species of copepods occurring in low-salinity areas (0.5 to $10 \mathrm{psu}$ ) of the northern SFE: Limnoithona tetraspina (Cyclopoida), Eurytemora affinis, and Pseudodiaptomus forbesi (Calanoida). Carbon and nitrogen content data for adult L. tetraspina were obtained from previously published relationships to length for related Oithona species (Uye 1982). Carbon and nitrogen data for $E$. affinis and $P$. forbesi were obtained by collecting 3 separate replicates of 15 female and male copepods each from Suisun Bay, drying each replicate on acid-washed septa at $60^{\circ} \mathrm{C}$ for 15 to $20 \mathrm{~min}$, and then transferring them to foil cups for an extended drying period of $12 \mathrm{~h}$ at $60^{\circ} \mathrm{C}$. Replicate samples, including blanks, were analyzed on a PE II 2400 CHN Analyzer at the University of California at Davis Stable Isotope Laboratory (Table 1).

Five natural prey-field grazing incubations were carried out between October 2003 and May 2004 using the adult stages of Limnoithona tetraspina. In April and May 2004, grazing incubations were also carried out using Eurytemora affinis and Pseudodiaptomus forbesi. Copepods, natural water samples for feeding incubations, and temperature and salinity data were collected from 3 different sites in Suisun Bay (Fig. 1). Field collection and experimental methods were adapted from previously published protocols (Båmstedt et al. 2000, Rollwagen Bollens \& Penry 2003). Copepods were collected from Suisun Bay with a $100 \mu \mathrm{m}$ mesh net using a gentle subsurface tow. Water samples used for experimental incubations were collected from the surface using a clean bucket and immediately back-siphoned gently into an insulated carboy through a submerged $200 \mu \mathrm{m}$ mesh to remove all large grazers. Water samples were not filtered after this initial screening to prevent damage to fragile cells. Water samples were also collected to determine ambi-

Table 1. Limnoithona tetraspina, Eurytemora affinis and Pseudodiaptomus forbesi. Mean $( \pm 95 \% \mathrm{CI})$ carbon and nitrogen content of adult copepods $\left(\mu\right.$ copepod $\left.^{-1}\right)$. Calanoid samples were collected from Suisun Bay in April 2003. Data for L. tetraspina from published length-weight relationships for Oithona (Uye 1982)

\begin{tabular}{|lcc|}
\hline Species & Carbon & Nitrogen \\
\hline L. tetraspina & 0.27 & 0.06 \\
P. forbesi females & $3.53(0.83)$ & $0.67(0.23)$ \\
P. forbesi males & $1.55(4.70)$ & $0.28(0.95)$ \\
E. affinis females & $2.00(1.30)$ & $0.35(0.23)$ \\
E. affinis males & $1.49(1.10)$ & $0.31(0.21)$ \\
\hline
\end{tabular}


ent chl a concentrations at each study site, except for the October experiment (for which we have no chl a data), and the February experiment when we used chl a data collected by a USGS research vessel on the same day from stations adjacent to the Martinez pier (USGS Stns 7 to 10, unpubl. data, sfbay.wr.usgs.gov/ access/wqdata/). Water samples were collected from the surface in clean Nalgene bottles and immediately stored in the dark on ice. In the laboratory 3 replicate $50 \mathrm{ml}$ water samples were filtered onto either GF/F filters or $5 \mu \mathrm{m}$ polycarbonate filters, and both sets of filters were extracted in $90 \%$ acetone for $24 \mathrm{~h}$. Blank filters were simultaneously extracted. Standard fluorometric techniques using acidification were used to measure in vitro chl a concentration (Holm-Hansen et al. 1965) on a calibrated Turner 10-AU fluorometer. $\mathrm{Chl}$ a concentrations were $<3 \mu \mathrm{g} \mathrm{l}^{-1}$ for all experiments, peaking slightly during the May experiment at $2.5 \mu \mathrm{g}$ $\mathrm{l}^{-1}$. The fraction of ambient $\mathrm{chl} a>5.0 \mu \mathrm{m}$ ranged from $76 \%$ in March 2004 to $68 \%$ in May 2004 (Table 2).

For the grazing experiments, copepods and natural water samples were returned to the lab within $2 \mathrm{~h}$ of collection and stored in a constant-temperature room at in situ field temperatures. Copepods were sorted while detritus-rich water collected from Suisun Bay for experimental incubation purposes was settled out in a carboy for approximately $3 \mathrm{~h}$. The top $80 \%$ of the contents of the carboy was then gently siphoned into a clean bucket, mixed thoroughly, and allocated to the respective treatment bottles. Treatments included 3 or 4 replicate initial, control, and experimental bottles (Table 3). At the start of each experiment, 62 to 74 copepods were added to the $175 \mathrm{ml}$ experimental bottles and all treatment bottles were filled with Suisun Bay water, sealed with parafilm, and capped to prevent the formation of air bubbles. All treatments were incubated on a plankton wheel at 1 revolution $\mathrm{min}^{-1}$ for $24 \mathrm{~h}$ at field temperatures on a $12: 12 \mathrm{~h}$ light:dark cycle, except the initial treatments which were removed from the plankton wheel after $1 \mathrm{~h}$. All treatments were preserved immediately after removal from the wheel in a $10 \%$ acid Lugol's solution.

Using the Utermöhl method, samples from preserved incubation treatments were settled through $27 \mathrm{ml}$ columns into settling chambers, and the entire area of the chamber was counted for ciliates and diatoms using an inverted microscope at $200 \times$ magnification. Counts of cells for all taxa combined typically exceeded 200 per chamber. Since the large quantity of detrital clumps prevented accurate counts of cells smaller than $10 \mu \mathrm{m}$ using these methods, we excluded small flagellates from our analyses. Counts for all experiments were completed within $45 \mathrm{~d}$ of the experiment, with the exception of the October 2003 experiment, which was analyzed within 90 d. All taxa grazed were measured and assigned a geometric shape for volume estimates. Carbon biomass was calculated for aloricate ciliates using a carbon-to-volume ratio of $0.22 \mathrm{pg}$ carbon $\mu^{-3}$ (Stoecker et al. 1994), and for loricate cells using previously-published relationships to biovolume (Menden-Deuer \& Lessard 2000) assuming a lorica:cell volume of 0.35 (Rollwagen Bollens \& Penry 2003). To determine significant decreases in prey resulting from grazing by copepods, control and experimental cell concentrations were compared ( $t$-test, equal variance) for all taxonomic groups that were more abundant than 10 cells per $27 \mathrm{ml}$. Clearance and ingestion rates with $95 \%$ confidence limits were calculated for all prey taxonomic categories using the equations of Marin et al. (1986), and daily ration was calculated according to Båmstedt et al. (2000).

The concentration of copepods in experimental containers ( 70 per $175 \mathrm{ml})$ was selected to ensure that any feeding could be detected. In terms of biomass this concentration $\left(\sim 110 \mu \mathrm{g} \mathrm{C}^{-1}\right)$ is similar to that used in other feeding experiments (e.g. Rollwagen Bollens \&

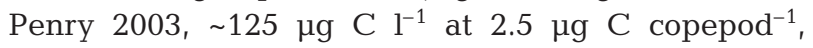

Table 2. Surface salinity (psu), temperature $\left({ }^{\circ} \mathrm{C}\right)$, and chl a $\left(\mu \mathrm{g}^{-1}\right)$ at copepod and natural-water sampling locations along Suisun Bay. nd: no data

\begin{tabular}{|lccccc|}
\hline \multirow{2}{*}{ Date } & \multirow{2}{*}{ Sample site } & Salinity & \multirow{2}{*}{ Temp. } & \multicolumn{2}{c|}{ Chl a } \\
& & & & GF/F & $>5 \mu \mathrm{m}$ \\
\hline 27 Oct 2003 & Antioch Pier & 1.2 & 21.1 & nd & nd \\
10 Feb 2004 & Martinez Pier & 4.5 & 10 & 2.2 & nd \\
30 Mar 2004 & Martinez Pier & 9.5 & 15 & 2.1 & 1.6 \\
24 Apr 2004 & Martinez Pier & 3.5 & 15 & 0.9 & 0.7 \\
18 May 2004 & Port Chicago & 1.8 & 18 & 2.5 & 1.7 \\
\hline
\end{tabular}

Table 3. Limnoithona tetraspina, Eurytemora affinis and Pseudodiaptomus forbesi. Number of copepods and incubator volumes (ml) used to measure copepod grazing on Suisun Bay plankton assemblages

\begin{tabular}{|c|c|c|c|c|c|}
\hline Experiment & $\begin{array}{l}\text { No. of } \\
\text { replicates }\end{array}$ & Species & Gender & $\begin{array}{l}\text { No. of } \\
\text { copepods }\end{array}$ & $\begin{array}{l}\text { Incubator } \\
\text { volume }\end{array}$ \\
\hline 27 Oct 2003 & 4 & L. tetraspina & o & $68-74$ & 175 \\
\hline 10 Feb 2004 & 4 & L. tetraspina & 우 & $62-77$ & 175 \\
\hline 30 Mar 2004 & 4 & L. tetraspina & 우 & $65-78$ & 175 \\
\hline 24 Apr 2004 & 4 & L. tetraspina & 우 & $72-75$ & 175 \\
\hline 24 Apr 2004 & 3 & E.affinis & $\left(5,, 5 o^{7}\right)$ & 10 & 600 \\
\hline 18 May 2004 & 4 & L. tetraspina & 우 & $68-77$ & 175 \\
\hline 18 May 2004 & 4 & P. forbesi & 우 & 10 & 600 \\
\hline
\end{tabular}


weight from W. J. Kimmerer unpubl.). Nevertheless, the large calculated reductions in food concentration in some experiments (see 'Results') suggest that calculated grazing rates might be underestimated in some experiments. To further study selection by Limnoithona tetraspina of motile or non-motile prey, we also ran separate grazing experiments using cultured phytoplankton. L. tetraspina were starved for $1 \mathrm{~h}$, after which sets of 5 to 10 copepods were incubated separately in cultures of either Rhodomonas salina, Thallasiosira weissflogii, or Skeletonema costatum. After allowing copepods to graze on separate groups of phytoplankton for up to $1 \mathrm{~h}$, live copepods were observed under blue (450 to $490 \mathrm{~nm}$ ) and green (510 to $560 \mathrm{~nm}$ ) light with a Nikon Eclipse E400 epifluorescence microscope at 200 to $400 \times$ magnification and visually analyzed for gut fluorescence. In addition, L. tetraspina were collected from surface waters offshore of Port Chicago in Suisun Bay on May 17, 2004 and analyzed for chl a gut fluorescence. Calculations to determine chl a gut content of copepods were made according to Båmstedt et al. (2000).

We also determined the egg production rate of Limnoithona tetraspina using samples collected from Suisun Bay on 17 occasions between 1999 and 2001 (Kimmerer et al. 2005). Copepod samples were taken approximately monthly using a $50 \mu \mathrm{m}$ mesh, $50 \mathrm{~cm}$ diameter net towed vertically through the water column at a single station in Suisun Bay. Measurements were also made of temperature and salinity using a Seabird SBE-19 CTD, and chlorophyll concentration by extracted fluorescence as described above (Kimmerer et al. 2005). Copepods were identified and the number of egg sacs was determined. A subsample of 20 egg sacs from 11 samples had an average of 6 eggs per sac, and these were used to calculate eggs per female. Loose eggs in some samples were also counted and assigned to $L$. tetraspina in proportion to its abundance relative to total Oithonids. A total of 48 to 243 females $($ median $=127)$ were counted and 0 to 138 (median $=24$ ) eggs estimated for L. tetraspina. Egg production rate and weight-specific rate were estimated using temperature-dependent egg development times and egg carbon content $(7.4 \mathrm{ng} \mathrm{C})$ for Oithona davisae (Uye \& Sano 1995).

\section{RESULTS}

Limnoithona tetraspina occupied higher salinities and also occurred at densities an order of magnitude higher than its congener $L$. sinensis (Fig. 2). Of the L. tetraspina population, $80 \%$ occurred within the 0.5 to 10 psu salinity range, and the population was most abundant $\left(>20000 \mathrm{~m}^{-3}\right)$ during the late summer and

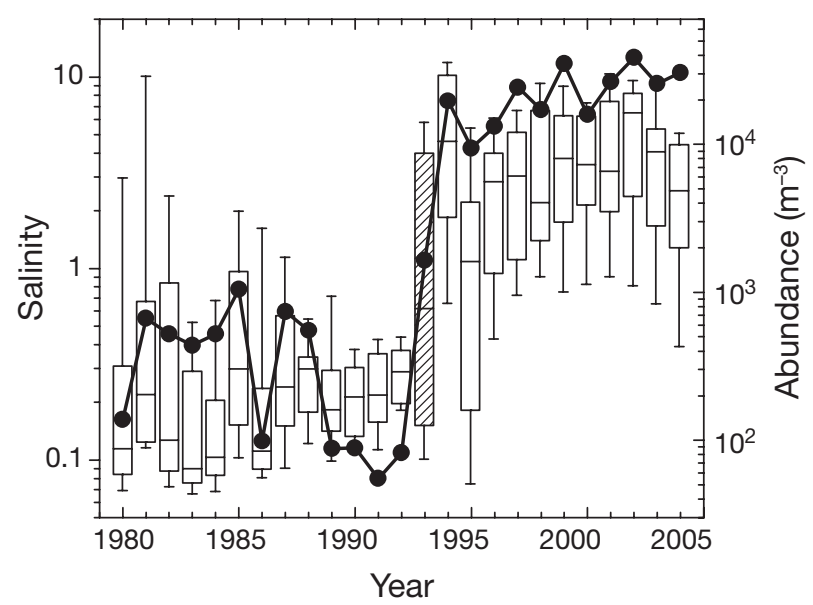

Fig. 2. Limnoithona sinensis and Limnoithona tetraspina. Abundance from monitoring data (species were not distinguished routinely). Line shows mean abundance in summer (July to October) for adult copepods. Box plot distribution of Limnoithona spp. in terms of salinity; boxes give medians with 90th, 75th, 25th and 10th percentiles. Hatched box indicates year (1993) in which L. tetraspina was first detected in the SFE, during and after which $L$. sinensis was no longer detected in Interagency Ecological Program zooplankton samples (IEP monitoring data)

fall, coincident with elevated water temperatures and periods of low phytoplankton biomass (i.e. chl a concentrations $<5 \mu \mathrm{g} \mathrm{l}^{-1}$; Fig. 3). Abundance of the adult L. tetraspina population was 1 to 2 orders of magnitude greater than those of the co-occurring calanoids Eurytemora affinis and Pseudodiaptomus forbesi, whereas the carbon and nitrogen biomass of adult L. tetraspina was roughly equivalent to that of adults of the larger calanoids (Fig. 4).

Both adult and immature stages of Limnoithona tetraspina behave as ambush predators that remain

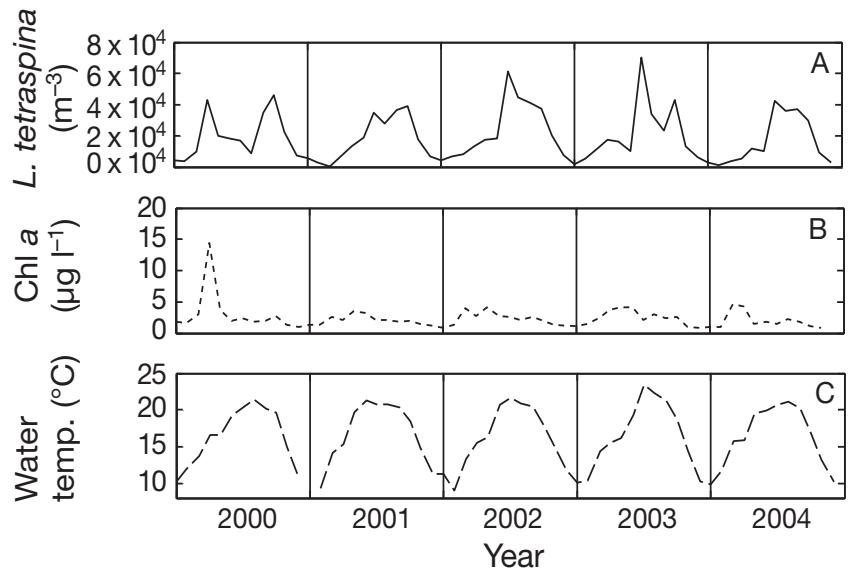

Fig. 3. Limnoithona tetraspina. (A) Mean monthly adult copepod abundance, (B) mean chl $a$, and (C) mean temperature in the 0.5 to 10 psu salinity range of the northern SFE (IEP monitoring data) 


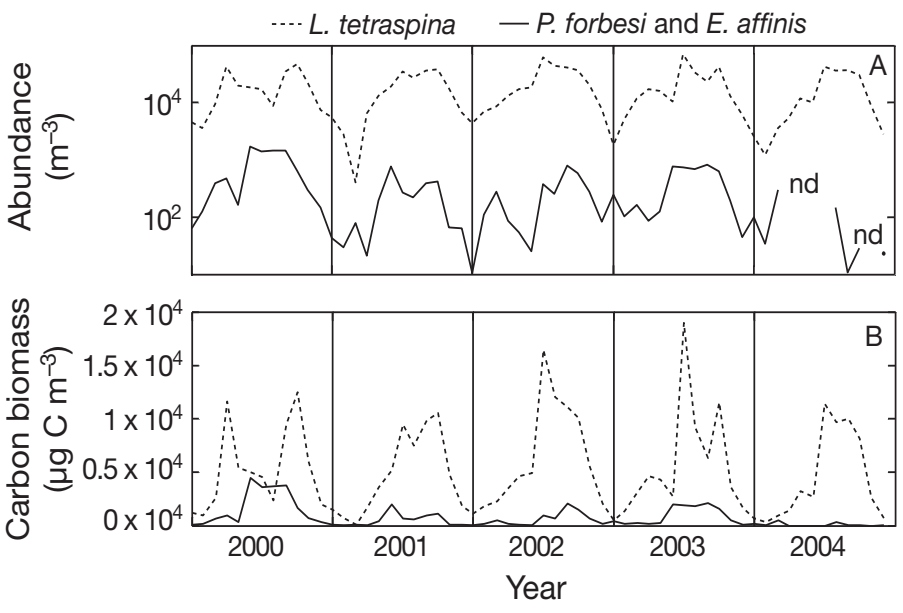

Fig. 4. Limnoithona tetraspina, Eurytemora affinis, and Pseudodiaptomus forbesi. (A) Mean adult abundance and (B) mean carbon biomass (nd: no data) in the northern SFE. All data are for salinity ranges $\geq 0.5$ and $<10 \mathrm{psu}$; data for calanoids are combined for comparison with $L$. tetraspina.

(IEP monitoring data)

relatively motionless in the water column before striking out towards motile prey; to date we have not observed a feeding current. Live capture and consumption of ciliates by adult copepods was directly observed under light microscopy. While capture of prey was not always successful, once capture occurred ciliates were ingested whole.

In situ gut pigment analyses of Limnoithona tetraspina adults collected from Suisun Bay showed that chl a pigments were an order of magnitude higher in copepods collected directly from the field $1.2 \times 10^{-3} \mathrm{\mu g}$ $\mathrm{chl}$ a copepod ${ }^{-1}$ ) than for copepods starved for $24 \mathrm{~h}$ in GF/F water $\left(0.4 \times 10^{-3} \mu \mathrm{g}\right.$ chl a copepod $\left.^{-1}\right)$. Grazing on cultured phytoplankton sources, as detected by gut fluorescence, was observed only for copepods incubated with the motile phytoflagellate Rhodomonas salina (length $=7 \mu \mathrm{m}$, width $=5 \mu \mathrm{m}$ ). Guts of copepods that had been incubated with $R$. salina fluoresced brightly under both blue and green excitation. We saw a single diatom cell, Thalassiosira weissflogii (length = $15 \mu \mathrm{m}$, width $=7.5 \mu \mathrm{m}$ ), in the gut of a single copepod; otherwise there was no evidence of feeding on this diatom or on Skeletonema costatum (length = $7 \mu \mathrm{m}$, width $=5 \mu \mathrm{m})$.

Abundance of heterotrophic aloricate ciliates in Suisun Bay was greatest during the spring (April and May) experiments (Table 4), while mixotrophic aloricates (i.e. Mesodinium sp.) and heterotrophic loricates usually occurred at low relative abundances. Diatoms were most abundant in March when Skeletonema costatum dominated the prey-field, and during the October experiment when Chaeotoceros sp. and pennate diatoms were dominant in the plankton. In the April 2004 experiment no diatoms were detected, and dinoflagellates were detected only in May 2004. Total prey abundances were highest in February as a result of the $S$. costatum bloom.

During the October and March experiments no grazing by Limnoithona tetraspina was detected on diatoms although they dominated the prey field (Table 5). Grazing on diatoms was detected in only 1 of 5 experiments. Grazing was detected on ciliates in all experiments, but grazing rates depended on the ciliate taxon. For instance, a significant grazing effect was detected on heterotrophic aloricate ciliates in all 5 experiments, but grazing on heterotrophic loricate ciliates was detected only 1 of 5 times. Two size-morphs of Mesodinium rubrum (length $=18 \mu \mathrm{m}$ and length $=28 \mu \mathrm{m}$ ) were observed during each experiment, but grazing was detected only on the smaller-sized form. Daily rations of $L$. tetraspina feeding on ciliates, measured as the percentage of copepod carbon consumed as ciliates $\mathrm{d}^{-1}$, ranged from 0.6 to $8 \% \mathrm{~d}^{-1}$.

Significant grazing on heterotrophic aloricate and loricate ciliates was observed for both Eurytemora affinis (mean ingestion rate $=5 \pm 3$ ciliates copepod ${ }^{-1} \mathrm{~h}^{-1}$ $(95 \% \mathrm{CI})$, and daily ration $=34 \pm 7 \%)$, and Pseudodiaptomus forbesi (average ingestion rate $=8 \pm 4$, and daily ration $=40 \pm 22 \%$ ). Unlike Limnoithona tetraspina, $P$. forbesi also grazed on diatoms and dinoflagellates that were present. No diatoms were present in plankton samples at the time of the Eurytemora affinis grazing experiment, but we have previously maintained cultures of this copepod on diatoms (W. J. Kimmerer unpubl.). These experiments demonstrated partial overlap in the diets of $L$. tetraspina and the larger calanoids, although clearance rates for $E$. affinis (mean clearance rates $=32$ to $33 \mathrm{ml}$ copepod $^{-1} \mathrm{~d}^{-1}$ ) and $P$. forbesi (mean clearance rate $=28$ to $50 \mathrm{ml}_{\text {copepod }}{ }^{-1}$ $\mathrm{d}^{-1}$ ) were an order of magnitude higher than those of the smaller cyclopoids.

Table 4. Initial concentrations for all potential prey taxa $(>10 \mu \mathrm{m})$ present in water samples collected for Suisun Bay copepod grazing incubations (cells $\mathrm{ml}^{-1}$; mean $\pm 95 \% \mathrm{CI})$. np: not present

\begin{tabular}{|c|c|c|c|c|c|}
\hline Experiment & $\begin{array}{l}\text { Heterotrophic } \\
\text { aloricate }\end{array}$ & $\begin{array}{l}\text { Mixotrophic } \\
\text { aloricate }\end{array}$ & $\begin{array}{l}\text { Heterotrophic } \\
\text { loricate }\end{array}$ & Diatoms & $\begin{array}{c}\text { Dino- } \\
\text { flagellates }\end{array}$ \\
\hline Oct 2003 & $3.2 \pm 0.9$ & $1.5 \pm 0.4$ & $0.9 \pm 0.4$ & $6.5 \pm 1.3$ & $\mathrm{np}$ \\
\hline Feb 2004 & $1.1 \pm 0.2$ & $1.2 \pm 0.1$ & $1.5 \pm 0.3$ & $0.4 \pm 0.1$ & np \\
\hline Mar 2004 & $1.7 \pm 0.3$ & $\mathrm{np}$ & $0.9 \pm 0.2$ & $61.2 \pm 6.1$ & np \\
\hline Apr 2004 & $10.7 \pm 0.5$ & np & $1.2 \pm 0.1$ & $\mathrm{np}$ & $\mathrm{np}$ \\
\hline May 2004 & $7.9 \pm 0.7$ & $0.8 \pm 0.3$ & $1.0 \pm 0.2$ & $1.4 \pm 0.3$ & $30.8 \pm 0.3$ \\
\hline
\end{tabular}


Table 5. Limnoithona tetraspina. Prey abundance for all incubations (cells $\mathrm{ml}^{-1}$; mean $\pm 95 \% \mathrm{CI}$ ), and $t$-test comparison of prey abundance for control versus grazed incubators at $t=24 \mathrm{~h} .{ }^{* * *} \mathrm{p}<0.001,{ }^{* *} \mathrm{p}<0.01,{ }^{*} \mathrm{p}<0.05$; ns $=$ non-significant $(\mathrm{p}>0.05)$

\begin{tabular}{|c|c|c|c|c|c|}
\hline \multirow[t]{2}{*}{ Expt } & \multirow[t]{2}{*}{ Prey field } & & \multirow[b]{2}{*}{ Initial } & \multicolumn{2}{|c|}{ Cells $\mathrm{ml}^{-1}(95 \% \mathrm{CI})-$} \\
\hline & & & & Control $t_{24}$ & Copepods $t_{24}$ \\
\hline \multirow[t]{15}{*}{ October 2003} & & $\mathrm{n}=$ & 3 & 4 & 4 \\
\hline & Strombidium sp. A & & $2.8 \pm 0.8$ & $4.9 \pm 0.8$ & $2.3 \pm 1.1^{* *}$ \\
\hline & Strombidium sp. B & & $0.4 \pm 0.1$ & $0.6 \pm 0.2$ & $0.0 \pm 0.0^{* *}$ \\
\hline & Mesodinium sp. (large) & & $0.2 \pm 0.1$ & $0.2 \pm 0.1$ & $0.1 \pm 0.0^{\mathrm{ns}}$ \\
\hline & Mesodinium sp. (small) & & $1.3 \pm 0.3$ & $2.0 \pm 0.2$ & $0.5 \pm 0.3^{* * *}$ \\
\hline & Total Aloricate Ciliates & & $4.7 \pm 1.3$ & $7.7 \pm 0.8$ & $2.9 \pm 1.2^{* * *}$ \\
\hline & Codonellopsis sp. A & & $0.5 \pm 0.3$ & $1.6 \pm 0.5$ & $1.8 \pm 0.6^{\mathrm{ns}}$ \\
\hline & Tintinnid sp. A & & $0.4 \pm 0.2$ & $0.7 \pm 0.3$ & $0.4 \pm 0.1^{\mathrm{ns}}$ \\
\hline & Total Loricate Ciliates & & $0.9 \pm 0.4$ & $2.3 \pm 0.5$ & $2.2 \pm 0.7^{\mathrm{ns}}$ \\
\hline & Amphiprora sp. & & $1.1 \pm 0.3$ & $1.0 \pm 0.3$ & $0.7 \pm 0.6^{\mathrm{ns}}$ \\
\hline & Chaetoceros sp. & & $4.7 \pm 1.2$ & $7.0 \pm 0.5$ & $4.7 \pm 3.0^{\mathrm{ns}}$ \\
\hline & Navicula sp. & & $0.1 \pm 0.2$ & $0.2 \pm 0.0$ & $0.1 \pm 0.1^{\mathrm{ns}}$ \\
\hline & Pleurosigma sp. & & $0.3 \pm 0.1$ & $0.1 \pm 0.0$ & $0.2 \pm 0.1^{\mathrm{ns}}$ \\
\hline & Other centric diatoms & & $0.2 \pm 0.1$ & $0.2 \pm 0.1$ & $0.2 \pm 0.1^{\mathrm{ns}}$ \\
\hline & Total Diatoms & & $6.5 \pm 1.3$ & $8.4 \pm 0.7$ & $5.9 \pm 2.8^{\mathrm{ns}}$ \\
\hline \multirow[t]{7}{*}{ February 2004} & & $\mathrm{n}=$ & 4 & 5 & 4 \\
\hline & Strombidium sp. C & & $1.1 \pm 0.15$ & $1.3 \pm 0.1$ & $0.7 \pm 0.3^{* *}$ \\
\hline & Mesodinium sp. (large) & & $0.8 \pm 0.0$ & $0.7 \pm 0.1$ & $0.5 \pm 0.2^{\mathrm{ns}}$ \\
\hline & Mesodinium sp. (small) & & $0.4 \pm 0.1$ & $0.5 \pm 0.0$ & $0.2 \pm 0.1^{* * *}$ \\
\hline & Total Aloricate Ciliates & & $2.2 \pm 0.2$ & $2.4 \pm 0.2$ & $1.4 \pm 0.4^{* *}$ \\
\hline & Total Loricate Ciliates - Tintinnid sp. B & & $1.5 \pm 0.3$ & $1.3 \pm 0.2$ & $1.1 \pm 0.1^{\mathrm{ns}}$ \\
\hline & Total Diatoms - Amphiprora sp. & & $0.4 \pm 0.1$ & $0.4 \pm 0.1$ & $0.3 \pm 0.1^{*}$ \\
\hline \multirow[t]{7}{*}{ March 2004} & & $\mathrm{n}=$ & 5 & 5 & 4 \\
\hline & Strombidium sp. D & & $1.7 \pm 0.3$ & $3.1 \pm 0.3$ & $1.3 \pm 0.3^{* * *}$ \\
\hline & Tintinnid sp. C & & $0.9 \pm 0.2$ & $1.7 \pm 0.3$ & $0.9 \pm 0.3^{* *}$ \\
\hline & Total Ciliates & & $2.6 \pm 0.4$ & $4.8 \pm 0.4$ & $2.2 \pm 0.5^{* * *}$ \\
\hline & Skeletonema costatum & & $61 \pm 49$ & $66 \pm 17$ & $75 \pm 11^{\mathrm{ns}}$ \\
\hline & Amphiprora sp. & & $0.7 \pm 0.2$ & $0.6 \pm 0.2$ & $0.7 \pm 0.2^{\mathrm{ns}}$ \\
\hline & Total Diatoms & & $61 \pm 49$ & $66 \pm 16$ & $76 \pm 11^{\mathrm{ns}}$ \\
\hline \multirow[t]{5}{*}{ April 2004} & & $\mathrm{n}=$ & 4 & 4 & 4 \\
\hline & Strombidium sp. E & & $5.8 \pm 0.5$ & $9.9 \pm 1.8$ & $6.4 \pm 1.2^{* *}$ \\
\hline & Unidentified sp. & & $4.9 \pm 0.3$ & $4.7 \pm 0.5$ & $3.5 \pm 0.5^{* *}$ \\
\hline & Total Aloricate Ciliates & & $11 \pm 0.5$ & $15 \pm 2.0$ & $10 \pm 1.4^{* *}$ \\
\hline & Total Loricate Ciliates - Tintinnid sp. D & & $1.2 \pm 0.1$ & $1.2 \pm 0.3$ & $1.2 \pm 0.1^{\mathrm{ns}}$ \\
\hline \multirow[t]{10}{*}{ May 2004} & & $\mathrm{n}=$ & 4 & 4 & 4 \\
\hline & Strombidium sp. F & & $7.0 \pm 0.6$ & $10 \pm 1.0$ & $8.2 \pm 1.4^{*}$ \\
\hline & Unidentified ciliate A & & $0.8 \pm 0.1$ & $0.5 \pm 0.1$ & $0.5 \pm 0.2^{\mathrm{ns}}$ \\
\hline & Mesodinium sp. (large) & & $0.5 \pm 0.2$ & $0.3 \pm 0.1$ & $0.3 \pm 0.1^{\mathrm{ns}}$ \\
\hline & Mesodinium sp. (small) & & $0.2 \pm 0.1$ & $0.3 \pm 0.3$ & $0.1 \pm 0.1^{\mathrm{ns}}$ \\
\hline & Total Aloricate Ciliates & & $8.6 \pm 0.9$ & $11 \pm 1.4$ & $8.9 \pm 1.5$ \\
\hline & Total Loricate Ciliates - Tintinnid sp. E & & $1.0 \pm 0.2$ & $0.9 \pm 0.5$ & $0.5 \pm 0.2^{\mathrm{ns}}$ \\
\hline & Ciliates & & $18.9 \pm 1.5$ & $12.3 \pm 1.8$ & $9.5 \pm 1.5^{*}$ \\
\hline & Total Dinoflagellates - Unidentified sp. & & $0.8 \pm 0.3$ & $0.6 \pm 0.1$ & $0.5 \pm 0.1^{\mathrm{ns}}$ \\
\hline & Total Diatoms & & $1.4 \pm 0.3$ & $1.2 \pm 0.4$ & $0.9 \pm 0.1^{\mathrm{ns}}$ \\
\hline
\end{tabular}




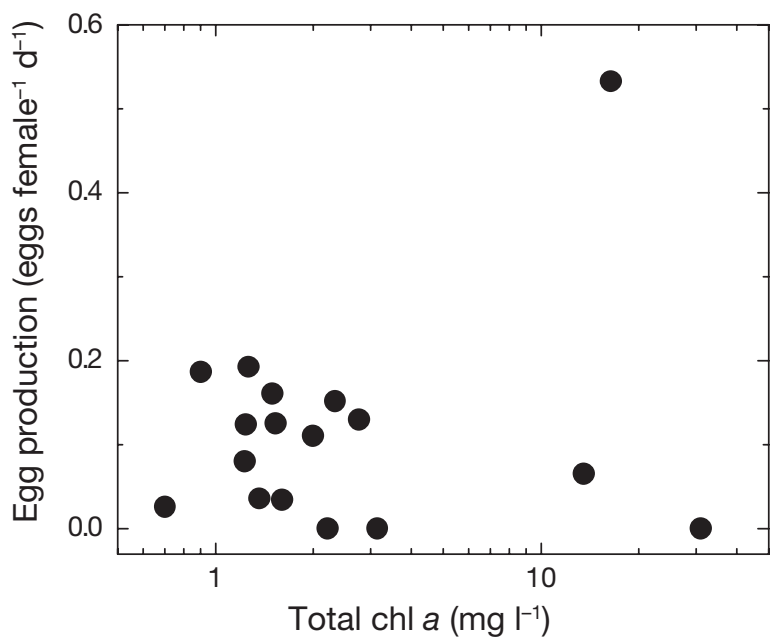

Fig. 5. Limnoithona tetraspina. Monthly egg production rate as a function of chl a in Suisun Bay during 17 mo between November 1999 and September 2001

Egg production rates of Limnoithona tetraspina averaged $0.2 \pm 0.1$ eggs female $\mathrm{e}^{-1} \mathrm{~d}^{-1}$ and were unrelated to chlorophyll concentration in Suisun Bay (Fig. 5). The mean egg production rate in weight-specific terms was $0.3 \% \mathrm{~d}^{-1}$.

\section{DISCUSSION}

Across a range of experimental conditions, and a wide geographic range, Oithona species are predominantly raptorial omnivores (Turner 2004) preying opportunistically on ciliates, autotrophic and heterotrophic flagellates, dinoflagellates, and copepod nauplii (Lampitt \& Gamble 1982, Turner 1986, Tsuda \& Nemoto 1988, Lonsdale et al. 2000). Feeding by oithonids on non-motile prey such as diatoms has been detected (Tsuda \& Nemoto 1988), but overall there is greater selection for motile taxa (Atkinson 1996) across a wide range of particle sizes ( 2 to $>20 \mu \mathrm{m}$, Lampitt \& Gamble 1982, Tsuda \& Nemoto 1988, Nakamura \& Turner 1997. Calbet et al. 2000). Additionally, Castellani et al. (2005) showed that oithonid metabolic demands are approximately 8 times lower than that of a calanoid copepod of equivalent body weight, which may help to explain the relatively high population abundances of oithonids across a wide range of habitats.

Our results show that, like Oithona spp., Limnoithona tetraspina is an omnivorous, raptorial copepod that consumes motile mixotrophic and heterotrophic ciliates with prey carbon content ranging between 560 and 5900 pg C cell ${ }^{-1}$, and phytoflagellates, but not diatoms (Table 5). Our analyses of gut-pigment showed that $L$. tetraspina consumed chl a in Suisun Bay. Since smallsized mixotrophic protozoans (Mesodinium sp.) were
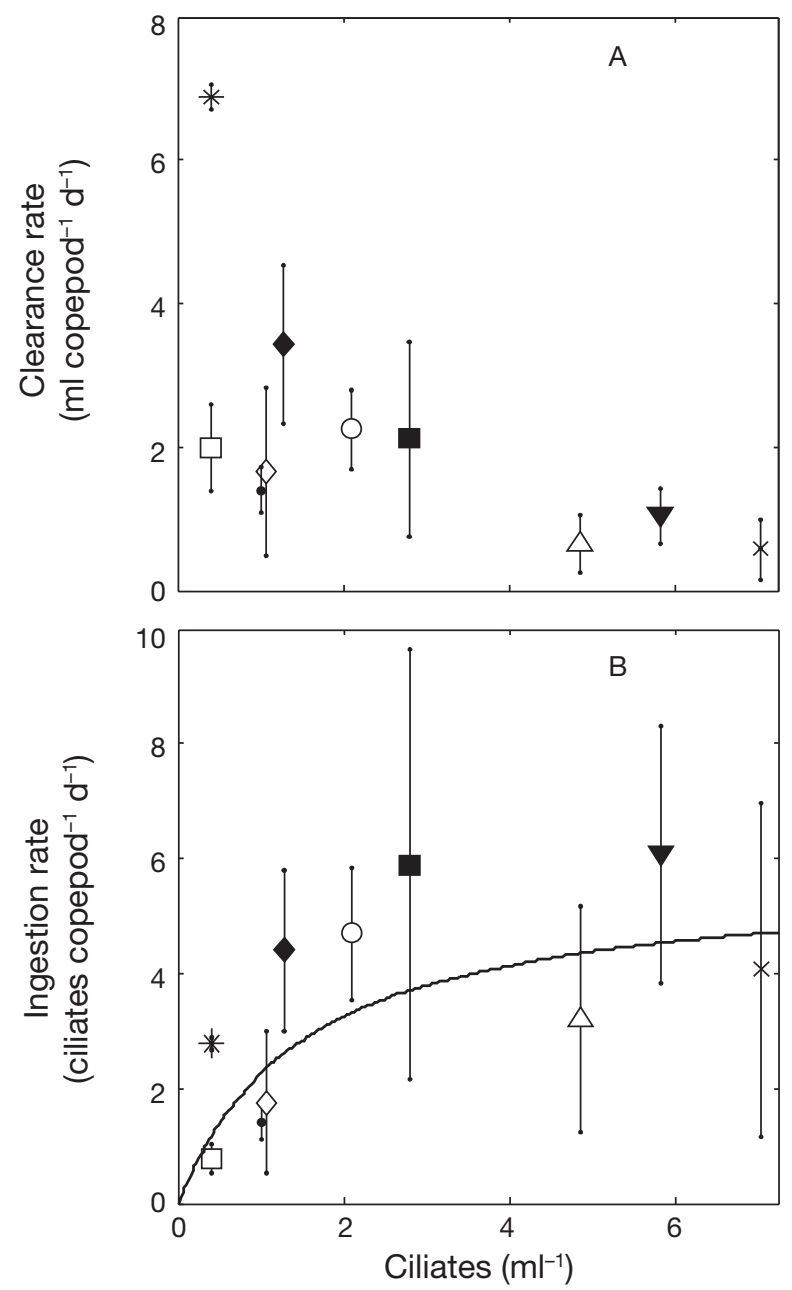

Fig. 6. Limnoithona tetraspina. (A) Clearance rates and (B) ingestion rates on naturally-occurring ciliates as a function of initial ciliate density. Bars show 95\% confidence intervals. The curved line in (B) is a rectangular hyperbola fitted to the data, (5.7 × Initial Prey Conc.) / (1.5 + Initial Prey Conc.). Strombidium A (ם), Strombidium B (*), Strombidium C ( $\square$ ), Strombidium D (O), Strombidium E $(\mathbf{\nabla})$, Strombidium F $(\times)$, Mesodinium A $(\diamond)$, Mesodinium B $(\diamond)$, Tintinnid B $(\bullet)$, Unidentified ciliate $(\Delta)$

present in these Suisun Bay samples, and concurrent incubation experiments confirmed predation on these taxa, it is likely that the gut chl a signal reflected predation on Mesodinium. The chl a signal may also have resulted from copepods grazing on naturally occurring phytoflagellates, which we were unable to count in our grazing experiments. While phytoflagellates may represent a potentially significant food source for $L$. tetraspina (as our gut-content experiments with monocultures of $R$. salina indicated), this would be surprising as L. tetraspina biomass peaks in the SFE during periods of very low phytoplankton biomass ( $\mathrm{chl} a<5 \mu \mathrm{g} \mathrm{l}^{-1}$ ) and egg production rates of Limnoithona in the SFE were unrelated to phytoplankton biomass (Fig. 5). 
Grazing rates determined in the incubation experiments may underestimate grazing under natural conditions, particularly in experiments in which proportional decreases in cell concentrations were large (e.g. March 2004 for Strombidium D). However, weightspecific egg production rates determined during 1999 to 2001 were very low, and with a gross growth efficiency of $\sim 30 \%$ imply weight-specific ingestion rates of $\sim 0$ to $5 \% \mathrm{~d}^{-1}$ (median $1 \% \mathrm{~d}^{-1}$ ), consistent with the range of rates we observed $\left(0.6\right.$ to $\left.8 \% \mathrm{~d}^{-1}\right)$. Our results for Limnoithona tetraspina ingestion rates are also consistent with the generally low metabolic rates characteristic of Oithonids (Castellini et al. 2005).

Mean clearance rates for all taxa across all experiments were highest for heterotrophic and mixotrophic aloricate ciliates reflecting selection for these motile taxa, consistent with the raptorial feeding behaviour of this copepod species (Fig. 6). Ingestion rates on ciliates increased with ciliate density, and a rectangular hyperbola provided a reasonably good fit to the ingestion rate data (Fig. 6).

Clearance rates for Limnoithona tetraspina (0.01 to $0.38 \mathrm{ml} \mathrm{copepod}^{-1} \mathrm{~h}^{-1}$ ) feeding on ciliates are similar to those reported for Oithona similis (0.03 to $0.38 \mathrm{ml}$ copepod $^{-1} \mathrm{~h}^{-1}$ ) in Buzzards Bay, Massachusetts (Nakamura \& Turner 1997). However, our ingestion rates for L. tetraspina were an order of magnitude lower (average $3.1 \pm 2.6$ cells copepod ${ }^{-1} \mathrm{~d}^{-1}$ ) than those found for O. similis in Buzzards Bay primarily as a result of low ciliate concentrations. The low ingestion rates and the saturated feeding on ciliates at the higher range of observed ciliate concentrations (Fig. 6) suggests that the population is food limited much of the time. This is consistent with observations from higher (Kimmerer et al. 2005) and lower (Mueller-Solger et al. 2002) salinity regions, where zooplankton were chronically foodlimited. It is also consistent with the persistently low level of phytoplankton biomass in the low-salinity region of the estuary since 1987 (Alpine \& Cloern 1992, Kimmerer 2004).

Nonetheless, we cannot rule out the possibility that other foods supplement ciliates in the diet of this copepod. Alternative food sources in Suisun Bay may include copepod nauplii, other pelagic larvae, nanoand micro-flagellates, and detritus. Limnoithona spp., like Oithona sp. (Gonzáles \& Smetacek 1994), could be utilizing sinking particulate matter as a food source. In Suisun Bay this particulate material is mostly associated with bacteria (Hollibaugh \& Wong 1999), and bacterial aggregation with larger particles may permit picoplankton-sized bacterial food sources to be more readily available to copepod grazers. As for feeding on copepod nauplii, preliminary investigations of Limnoithona feeding on Nauplius stages 1 and 2 of Eurytemora affinis incubation methods showed no predatory impact in that zero change in abundance of nauplii occurred in the experimental containers (P. Bouley unpubl.). Further experiments are needed to test these results. Naturally occurring phytoflagellates may be a significant food source, and further study on Limnoithona spp. feeding habits using methods developed for studying field populations of nanoflagellates should yield further insight.

Omnivory by copepods is prevalent in, but not restricted to, environments with low phytoplankton biomass, e.g. oligotrophic oceanic systems, or regions with high suspended particulate matter or nanophytoplankton (Gifford \& Dagg 1988, Ohman \& Runge 1994, Rollwagen Bollens \& Penry 2003). Phytoplankton biomass in the northern SFE is low compared to other estuarine systems (Alpine \& Cloern 1992, Kimmerer 2004). Bacterial production was estimated to exceed phytoplankton production by 5-fold during 1988 to 1989 (Hollibaugh \& Wong 1996) and a significant portion of phytoplankton carbon occurs in cells less than $10 \mu \mathrm{m}$ (Sobczak et al. 2002). Light limitation caused by high suspended particulate matter and benthic grazing are considered the primary reasons for low phytoplankton productivity in this turbid region (Alpine \& Cloern 1992). The invasion of the SFE by Corbula amurensis in 1986 (as Potamocorbula amurensis, Nichols et al. 1990) eliminated the summer high-phytoplankton biomass in Suisun Bay previously associated with periods of low outflow and high residence time (Alpine \& Cloern 1992). Chl a concentrations decreased by $69 \%$ between pre- and postC. amurensis years (Kimmerer et al. 1994), concurrent with decreases in the proportion of cells in larger size classes, diatom abundance, and dissolved silica uptake in Suisun Bay and the lower Sacramento-San Joaquin Delta (Kimmerer 2004, 2005). The consequences of the above conditions in Suisun Bay included notable declines in abundance of some copepod and mysid shrimp species as a result of the reduction in food supply, as well as predation on nauplii by clams, and a reduction in abundance of several common fish species including northern anchovy (Kimmerer 2006, this volume).

In bays and estuaries where the dominant mode of predation is visual or benthic, predation can cause significant mortality of larger copepod prey favoring smaller, less visible copepods (Kimmerer 1991). Limnoithona tetraspina may be able to escape predation by predators using sight or hydro-mechanical signals because of 3 factors: (1) small copepod body size (500 $\mu \mathrm{m}$ total length, $0.27 \mu \mathrm{g}_{\text {carbon copepod }}{ }^{-1}$ ), (2) the relatively motionless behavior of all life stages, and (3) the ability of the copepods to detect and escape from predators.

The reduction of predation pressure on small pelagic copepods due to the decline of the northern anchovy, 
previously the biomass dominant among planktivores in Suisun Bay, may have facilitated the large increase in the Limnoithona population (Kimmerer 2006). We do not have gut composition for SFE anchovies, but significant predation by larval and juvenile anchovies on Oithona davisae, a similarly small marine oithonid, has been documented (Mitani 1988). Additionally, nauplii of small Oithona spp. are important prey for larval anchovy (Viñás \& Ramírez 1996). In addition, although L. tetraspina comprised as much as $80 \%$ of the SFE plankton during the summer and fall months between 1993 and 1996, it rarely made up more than $10 \%$ of the diet of juvenile delta smelt Hypomesus transpacificus, a visual predator, over that same period (Fig. 7).

In other systems dominated by small oithonids, small copepods are consumed primarily by non-visual, gelatinous predators. In Tokyo Bay, a eutrophic system dominated by Oithona davisae, jellyfish have been described as 'enormously successful' (Uye 1994). In Fukuyama Harbor, Japan, O. davisae typically dominated copepod abundances in the warm summer and fall months (Uye \& Liang 1998) but suffered declines due to cannibalism and during periods when lobate ctenophores (gelatinous predators) were abundant in the plankton (Uye \& Sano 1995). A similar pattern was observed in the Black Sea in the late 1980s as overexploitation led to the collapse of the Black Sea anchovy fishery. The subsequent abundance of mesozooplankton opened up a key trophic niche in the system that facilitated the rapid and successful invasion by the lobate ctenophore Mnemiopsis leidyi. The onceabundant, smaller-sized zooplankton suffered severe declines over this period and only began to shown signs of increase as jellyfish populations began to decline (Shiganova 1998). Three species of hydromedusae indigenous to the Black Sea have become established in small harbors of the SFE (Mills \& Rees 2000). However, gelatinous zooplankton overall do not occur

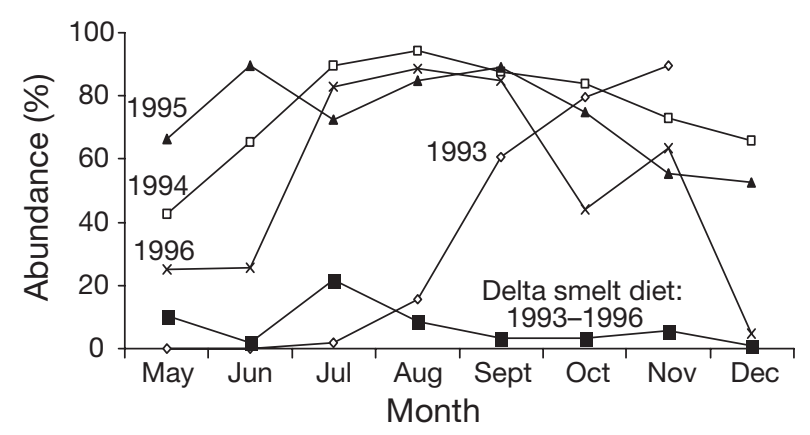

Fig. 7. Limnoithona tetraspina. Relative abundance among adult copepods in the plankton (IEP monitoring data for salinity of 0.5 to $10 \mathrm{psu}$ ) compared to the percentage of Limnoithona in the gut contents of juvenile Delta smelt between

May and December, 1993 to 1996 (data from Lott 1998) at significantly high abundances in open waters of the SFE (Orsi \& Mecum 1986, W. J. Kimmerer unpubl.) which may contribute to the high abundance of L. tetraspina.

Acknowledgements. We thank R. Larson, E. J. Carpenter, J. Durand, M. H. Nicolini and all our colleagues at San Francisco State University and the Romberg Tiburon Center for Environmental Studies for their generosity and support. We also thank J. J. Orsi and L. Mecum at the California Department of Fish and Game for providing copepod abundance data, and A. Müeller-Solger and G. Rollwagen Bollens for their very helpful comments and help with ciliate identification. We thank D. Marcal and N. Ferm for counting the egg ratio samples. This research was conducted in partial fulfillment of P.B.'s MS in Biology. Funding for this study was provided by CALFED Bay-Delta Program contract ERP-99-N09.

\section{LITERATURE CITED}

Alpine AE, Cloern JE (1992) Trophic interactions and direct physical effects control phytoplankton biomass and production in and estuary. Limnol Oceanogr 37:946-955

Atkinson A (1996) Subantarctic copepods in an oceanic, low chlorophyll environment: ciliate predation, food selectivity, and impact on prey populations. Mar Ecol Prog Ser 130:85-96

Atkinson A, Snÿder R (1997) Krill-copepod interactions at South Georgia, Antarctica, I. Omnivory by Euphausia superba. Mar Ecol Prog Ser 160:67-76

Båmstedt U, Gifford DJ, Irigoien X, Atkinson A, Roman MR (2000) Zooplankton feeding. In: Harris R, Wiebe P, Lenz J, Skoldal HR, Huntley M, (eds) ICES zooplankton methodology manual. Academic Press, New York, p 297-399

Calbet A, Landry MR, Scheinberg RD (2000) Copepod grazing in a subtropical bay: Species-specific responses to a midsummer increase in nanoplankton standing stock. Mar Ecol Prog Ser 193:75-84

Castellani C, Robinson C, Smith T, Lampitt RS (2005) Temperature affects respiration rate of Oithona similis. Mar Ecol Prog Ser 285:129-135

Cohen AN, Carlton JT (1998) Accelerating invasion rate in a highly invaded estuary. Science 279:555-558

Gifford DJ, Dagg DJ (1988) Feeding of the estuarine copepod Acartia tonsa Dana: carnivory vs herbivory in a natural microplankton assemblage. Bull Mar Sci 43:458-468

González HE, Smetacek V (1994) The possible role of the cyclopoid copepod Oithona in retarding vertical flux of zooplankton faecal material. Mar Ecol Prog Ser 113:233-246

Hiromi J (1995) Contribution of cyclopoid copepod Oithona davisae population to nutrient regeneration of Tokyo Bay during summer. Bull Coll Agric Vet Med Nihon Univ 52: 113-118

Hollibaugh JT, Wong PS (1996) Distribution and activity of bacterioplankton in San Francisco Bay. In: Hollibaugh JT (ed) San Francisco Bay: the ecosystem. Further investigations into the natural history of San Francisco Bay and Delta with references to the influence of man. Pac Div Am Assoc Adv Sci, San Francisco, CA, p 375-401

Hollibaugh JT, Wong PS (1999) Microbial processes in the San Francisco Bay estuarine turbidity maximum. Estuaries 22:848-862

Holm-Hansen O, Lorenzen CJ, Holmes RW, Strickland JDH (1965) Fluorometric determination of chlorophyll. J Cons Perm Int Explor Mer 30:3-15 
Kimmerer WJ (1991) Predatory influences on copepod distributions in coastal waters. Proc 4th Int Conf on Copepoda: Bull Plankton Soc Jpn, p 161-174

Kimmerer WJ (2004) Open water processes of the San Francisco Estuary: from physical forcing to biological responses. San Francisco Estuary and Watershed Science. Vol 2, Issue 1 (February 2004), Article 1. available at: http://repositories.cdlib.org/jmie/sfews/about.html

Kimmerer WJ (2005) Long-term changes in apparent uptake of silica in the San Francisco Estuary. Limnol Oceanogr 50: 793-798

Kimmerer WJ (2006) Response of anchovies dampens effects of the invasive bivalve Corbula amurensis on the San Francisco Estuary foodweb. Mar Ecol Prog Ser 324:207-218

Kimmerer WJ, Gartside E, Orsi JJ (1994) Predation by an introduced clam as the likely cause of substantial declines in zooplankton of San Francisco Bay. Mar Ecol Prog Ser 113:81-93

Kimmerer WJ, Nicolini MH, Ferm N, Peñalva C (2005) Chronic food limitation of egg production in populations of copepods of the genus Acartia in the San Francisco Estuary. Estuaries 28:541-550

Lampitt RS, Gamble JC (1982) Diet and respiration of the small planktonic marine copepod Oithona nana. Mar Biol 66:185-190

Lonsdale DJ, Caron DA, Dennett MR, Schaffner R (2000) Predation by Oithona spp. on protozooplankton in the Ross Sea, Antarctica. Deep-Sea Res II 47:3249-3272

Lott J (1998) Feeding habits of juvenile and adult delta smelt from the Sacramento-San Joaquin River Estuary. Interagency Ecological Program Newsletter 11:(1):14-19, available at: http://iep.water.ca.gov/report/newsletter/ 1998winter

Marin V, Huntley ME, Frost B (1986) Measuring feeding rates of pelagic herbivores: analysis of experimental design and methods. Mar Biol 93:49-58

Menden-Deuer S, Lessard EJ (2000) Carbon to volume relationshis for dinoflagellates, diatoms, and other protist plankton. Limnol Oceanogr 45:569-579

Mills CE, Rees JT (2000) New observations and corrections concerning the trio of invasive hydromedusae Maeotias marginata (=M. inexpectata), Blackfordia virginica and Moerisia sp. in the San Francisco Estuary. Sci Mar 64:151-155

Mitani I (1988) Food habits of Japanese anchovy in the Shirasu fishing ground within Sagami Bay. Bull Jpn Soc Fish 54:1859-1865

Müeller-Solger AB, Jassby AD, Müller-Navarra D (2002) Nutritional quality of food resources for zooplankton (Daphnia) in a tidal freshwater system (Sacramento-San Joaquin River Delta). Limnol Oceanogr 47:1468-1476

Nakamura Y, Turner JT (1997) Predation and respiration by the small cyclopoid copepod Oithona similis: How important is feeding on ciliates and heterotrophic flagellates? J Plankton Res 19:1275-1288

Nichols FH, Thompson JK, Schemel LE (1990) Remarkable invasion of San Francisco Bay (California, USA) by the Asian clam Potamocorbula amurensis. II. Displacement of a former community. Mar Ecol Prog Ser 66:95-101

Editorial responsibility: Barry \& Evelyn Sherr (Contributing Editors), Corvallis, Oregon, USA
Ohman MD, Runge JA (1994) Sustained fecundity when phytoplankton resources are in short supply: omnivory by Calanus finmarchicus in the Gulf of St. Lawrence. Limnol Oceanogr 39:21-36

Orsi JJ (1995) Food habits of several abundant zooplankton species in the Sacramento San Joaquin Estuary. California Department of Fish and Game Tech Rep 41

Orsi JJ, Mecum WI (1986) Zooplankton distribution and abundance in the Sacramento-San Joaquin Delta in relation to certain environmental factors. Estuaries 9:326-339

Orsi JJ, Ohtsuka S (1999) Introduction of the Asian copepods Acartiella sinensis, Tortanus destrilobatus (Copepoda: Calanoida), and Limnoithona tetraspina (Copepoda: Cyclopoida) to the San Francisco Estuary, California, USA. Plankton Biol Ecol 46:128-131

Rollwagen Bollens GC, Penry DL (2003) Feeding dynamics of Acartia spp. copepods in a large, temperate estuary (San Francisco Bay, CA). Mar Ecol Prog Ser 257:139-158

Shiganova TA (1998) Invasion of the Black Sea by the ctenophore Mnemiopsis leidyi and recent changes in pelagic community structure. Fish Oceanogr 7:305-310

Sobczak WV, Cloern JE, Jassby AD, Müller-Solger (2002) Bioavailability of organic matter in a highly disturbed estuary: the role of detrital and algal resources. Proc Acad Natl Sci USA 99:8101-8105

Stoecker DK, Gifford DJ, Putt M (1994) Preservation of marine planktonic ciliates: losses and cell shrinkage during fixation. Mar Ecol Prog Ser 110:293-299

Svensen C, and Kiørbe T (2000) Remote prey detection in Oithona similis: hydromechanical versus chemical cues. J Plantkon Res 22:1155-1166

Tsuda A, Nemoto T (1988) Feeding of copepods on natural suspended particles in Tokyo Bay. J Oceanogr Soc Jpn 44: 217-227

Turner JT (1986) Zooplankton feeding ecology: contents of fecal pellets of the cyclopoid copepods Oncaea venusta, Corycaeus amazonicus, Oithona plumifera, and O. simplex from the northern Gulf of Mexico. PSZN I: Mar Ecol 7:289-302

Turner JT (2004) The importance of small planktonic copepods and their roles in pelagic marine food webs. Zool Stud 43:255-266

Uye S (1982) Length-weight relationships of important zooplankton from the Inland Sea of Japan. J Oceanogr Soc Jpn 38:149-158

Uye S (1994) Replacement of large copepods by small ones with eutrophication of embayments: cause and consequence. Hydrobiologia 292-293:513-519

Uye S, Liang D (1998) Copepods attain high abundance, biomass and production in the absence of large predators but suffer cannibalistic loss. J Mar Syst 15:495-501

Uye S, Sano K (1995) Seasonal reproductive biology of the small cyclopoid copepod Oithona davisae in a temperate eutrophic inlet. Mar Ecol Prog Ser 118:121-128

Viñás MD, Ramirez FC (1996) Gut analysis of first-feeding anchovy larvae from the Patagonian spawning areas in relation to food availabilty. Arch Fish Mar Res 43: 231-256

Submitted: October 12, 2005; Accepted: March 22, 2006

Proofs received from author(s): September 29, 2006 